\title{
Dispersal in metamorphosing juvenile eel Anguilla anguilla
}

\author{
Eric Edeline ${ }^{1,2, *}$, Laurent Beaulaton ${ }^{1}$, Romaric Le Barh $^{1}$, Pierre Elie $^{1}$ \\ ${ }^{1}$ CEMAGREF, Unité de Recherche EPBX 'Ecosystèmes Estuariens et Poisons Migrateurs Amphihalins', 50 Avenue de Verdun, \\ 33612 Cestas cedex, France
}

${ }^{2}$ Present address: Centre for Ecological and Evolutionary Synthesis (CEES), University of Oslo, Dept. of Biology, PO Box 1066 Blindern, 0316 Oslo, Norway

\begin{abstract}
The morphological, physiological and behavioural changes occurring during metamorphosis reveal adaptations to drastic shifts in habitat and life style. We have investigated how dispersal behaviour changed during completion of the larval metamorphosis in migrating European eels Anguilla anguilla, as they reached the limit between the tidal and non-tidal parts of a large river. We show that late-metamorphic glass eels arriving from the sea rapidly migrated in the freshwater zone of the upper estuary by means of selective tidal stream transport. Then, due to the loss of tidal advection and despite the absence of an osmotic barrier, glass eels accumulated at the break point of tidal streams. Newly transformed small yellow eels were homogeneously distributed around the point where they initially accumulated as glass eels. This suggests that completion of larval metamorphosis induced the end of upstream migration (settlement) and a switch to density-dependent dispersal linked to food search. This ontogenetic pattern probably evolved to maximise growth through optimal utilisation of productive marine and estuarine habitats.
\end{abstract}

KEY WORDS: Developmental strategy $\cdot$ Evolution $\cdot$ Larvae $\cdot$ Metamorphosis $\cdot$ Teleost fish $\cdot$ Tidal stream transport · Hydrodynamics

\section{INTRODUCTION}

Metamorphosis is a suite of adaptive morphological, physiological and behavioural reorganisations evolved by numerous organisms to face acute changes in habitat and life style. Metamorphosis may therefore be considered a fitness-maximising developmental strategy (Moran 1994). We investigated the changes in dispersal behaviour associated with larval metamorphosis in the European eel Anguilla anguilla. Eels are marine, semelparous fishes, having ancestrally evolved a continental growth phase. In $A$. anguilla, the translucent, willow leaf-shaped leptocephalus larvae migrate from the Sargasso Sea to the European continental shelf, where they metamorphose into eel-shaped glass eels, a late-metamorphic developmental stage. This transformation is the first step of an adaptive shift from oceanic drift to continental life. Glass eels colonise coastal and estuarine waters using selective tidal stream transport (STST), a saltatory transport mechanism with alternations of flow-carried swimming during flood tide and benthic sheltering behaviour during ebb tides (McCleave \& Wippelhauser 1987). When they reach the tidal limit, migrating glass eels lose tidal advection and have to switch from STST to constant counter-current swimming to further colonise the watershed (McCleave \& Wippelhauser 1987). The details of this migration through transition zones between the tidal and non-tidal parts of estuarineriver systems have not previously been studied.

As glass eels migrate in coastal and estuarine waters, their body pigmentation develops, their digestive system is reorganised and new teeth grow (Elie 1979, Elie et al. 1982, Jegstrup \& Rosenkilde 2003, Tabeta \& Mochioka 2003). The true end of larval metamorphosis, marking the start of the growth phase ('yellow' stage), occurs with the full development of body pigmentation, of the gut and definitive teeth (Vilter 1945, 
Elie 1979, Jegstrup \& Rosenkilde 2003). The behavioural processes associated with the glass to yellow eel transition remain obscure. It is frequently observed that transformation into a yellow eel is associated with a transition from 'pelagic' to 'benthic' behaviour (Tesch 1977, Jegstrup \& Rosenkilde 2003). In many marine organisms, the onset of the juvenile phase triggers settlement after larval migration (Moran 1994). However, classically it has also been reported that yellow eels maintain upstream migration for 1 to $3 \mathrm{yr}$ of continental life (Tesch 1977), i.e. that the onset of the juvenile phase does not trigger settlement. We have investigated whether or not the glass to yellow eel transition (onset of the juvenile phase) triggers the end of upstream-oriented migration and settlement in the European eel. To do so, we have inferred dispersal ontogeny of metamorphosing eels from the distribution patterns of glass eels versus newly transformed yellow eels at the freshwater tidal limit of a large river.

\section{MATERIALS AND METHODS}

Study area. The study was conducted in the tidal limit area (TLA) of the Dordogne River in SW France. The Dordogne is $482 \mathrm{~km}$ long, drains a catchment of $23700 \mathrm{~km}^{2}$ and is free of barriers (falls or dam) in its lower reaches; the hydrological regime of its tidal limit is therefore natural. Hence, before reaching the nontidal river area, migrating fishes arriving from the sea encounter a long zone $(\sim 160 \mathrm{~km}$, see Table 1$)$, where tides induce both changes in current direction and water level, and then a short zone ( 15 km, see Table 1), where tides induce changes in water level only. In addition, on the Dordogne, the break point of tidal streams (interface between the 2 tidal zones) is located about $50 \mathrm{~km}$ upstream of the limit of the salinity front, providing a rare opportunity to separate the effects of hydrology and salinity on juvenile eel dispersal.

Sampling sites. Sampling sites were chosen to fit with these different tidal zones, as inferred from the hydro-physical study by Sottolicchio (1999), who, simi- lar to previous authors, reports that the limit of tidal influence is located about $160 \mathrm{~km}$ from the river mouth. However, the accurate break point of tidal streams is known by fishermen and river users to be located at Castillon la Bataille (Site C), due to a shallow of about $2 \mathrm{~m}$ depth where weakening tides break. Hence, the most downstream sampling sites, St Sulpice de Faleyrens (Site A) and Vignonet (Site B) were located in the part of the estuary where tides induced variations in both flow direction and water level, while Lamothe-Montravel (Site D) was located in the section of the estuary where tides induce variations in water level only. Finally, Pessac sur Dordogne (Site E), the most upstream sampling site, was located in the nontidal river area. Further details on habitat characteristics of the sampling sites are provided in Table 1.

Sampling protocol. Glass eels Anguilla anguilla are found all year round in the Bay of Biscay, but the highest abundance occurs between December and April (Elie \& Rochard 1994). Sampling was carried out during 2 'sampling years', from 21 February to 25 June 2002 and from 5 November 2002 to 10 July 2003. Sites $\mathrm{A}$ and $\mathrm{E}$ were sampled during the second sampling year, and Sites B, C and D were sampled during both sampling years. Fishes were sampled using artificial habitat collectors made from polyethylene thread tufts (vertically positioned artificial vegetation) inserted into a heavy $50 \times 60 \times 10 \mathrm{~cm}$ PVC base situated at the bottom. These collectors function as shelters and are highly efficient for juvenile eel sampling (Silberschneider et al. 2001). Sampling was undertaken by boat on the ebb tide in daylight; 5 or 6 collectors per sampling site were attached with ropes to the riparian vegetation and deposited 2 to $6 \mathrm{~m}$ from the shore. However, during floods, it was not possible to localise all collectors and thus fewer collectors were used for sampling on these occasions. Care was taken to avoid sites where aquatic vegetation could possibly compete with collectors as shelters. Moreover, the collectors were distributed along at least $100 \mathrm{~m}$ on both river banks in order to avoid patchy effects on abundance. Each time a collector was emptied, water depth was measured

Table 1. Habitat characteristics at each sampling site from which glass eels and newly transformed yellow eels Anguilla anguilla were sampled in the tidal limit area of the Dordogne River

\begin{tabular}{|c|c|c|c|c|c|c|c|c|}
\hline \multirow[t]{2}{*}{ Sampling site } & \multirow[t]{2}{*}{ Code } & \multirow[t]{2}{*}{$\begin{array}{l}\text { Times } \\
\text { sampled }\end{array}$} & \multirow{2}{*}{$\begin{array}{l}\text { Distance to } \\
\text { river mouth } \\
\quad(\mathrm{km})\end{array}$} & \multirow[t]{2}{*}{ Substrate } & \multicolumn{2}{|c|}{$\begin{array}{c}\text { Water depth of } \\
\text { sampling }(\mathrm{m})\end{array}$} & \multicolumn{2}{|c|}{$\begin{array}{l}\text { Water velocity } \\
\left(\text { ebb tide, } \mathrm{m} \mathrm{s}^{-1}\right)\end{array}$} \\
\hline & & & & & Range & Mean $\pm \mathrm{SD}$ & Range & Mean $\pm \mathrm{SD}$ \\
\hline St Sulpice de Faleyrens & $\mathrm{A}$ & 31 & 125 & Mud & $0.1-5$ & $1.67 \pm 0.91$ & $0-0.70$ & $0.30 \pm 0.18$ \\
\hline Vignonet & $\mathrm{B}$ & 41 & 134 & Mud + vegetal waste & $0.1-4.7$ & $1.69 \pm 0.83$ & $0-0.70$ & $0.22 \pm 0.16$ \\
\hline Castillon la Bataille & $\mathrm{C}$ & 53 & 156 & Sand + gravel & $0.1-4$ & $1.30 \pm 0.842$ & $0-0.90$ & $0.15 \pm 0.19$ \\
\hline Lamothe-Montravel & $\mathrm{D}$ & 41 & 163 & Sand + gravel & $0.3-5$ & $1.44 \pm 0.75$ & $0-0.72$ & $0.26 \pm 0.20$ \\
\hline Pessac sur Dordogne & $\mathrm{E}$ & 17 & 169 & Sand + mud & $0.2-3.7$ & $1.64 \pm 0.91$ & $0.01-0.8$ & $0.19 \pm 0.15$ \\
\hline
\end{tabular}


with a ballasted rope and current speed was measured with a Doppler current meter (Table 1).

Morphological analysis. The aim was to separate individuals into 2 classes: glass eels versus newly transformed yellow eels. Individuals of body length $<15 \mathrm{~cm}$ (i.e. $<1 \mathrm{yr}$ of continental life) were transported to the laboratory in aerated river water and frozen after anaesthesia in clove oil $(10 \%$ diluted in ethanol, $4 \mathrm{ml}$ $\mathrm{l}^{-1}$ ). After thawing, fishes were examined under the microscope for metamorphosis staging according to the extent of skin pigmentation over the head, tail and body regions, through Stages VB to VIB for glass eels and Stage VII for newly transformed yellow eels (Elie et al. 1982).

Data processing and statistical modelling. Inputmodelling data were the number of glass eels and small yellow eels at each sampling site and day $(\mathrm{N}=$ 183 sampling events, total catches $=2063$ eels). Abundances of both glass and yellow eels were skewed with a peak at zero. Therefore, following Stefánsson (1996), we analysed separately zero (i.e. presence $p$ ) and positive abundance values (mean abundance $\mu$ when fish were present) using generalised linear models (GLM, PROC GENMOD, SAS 8.0). Details concerning the GLM are presented in Table 2. We followed a model selection process based on Aikaike's information criterion (AIC) for each of the 4 models. AIC was recorded from models including all possible combinations of effects, and we retained the mostparsimonious models (i.e. those having the lowest AIC) in which each effect was statistically significant (Type III sum of squares). The tested effects were as follows: (1) number of collectors used at each sampling site; (2) river discharge at Pessac sur Dordogne (Site E), classified into 4 classes according to the quartiles for the period 1997 to 2003, as provided by the French Data Bank for Hydrology (www.hydro. eaufrance.fr/); (3) sampling year, from 21 February 2002 to 25 June 2002 and from 5 November 2002 to 10 July 2003 ; (4) sampling sites, corresponding to different distances from the river mouth. (5) Tidal periods were long-term tidal oscillations defined according to a tide calendar, and corresponded to the 3 steps of glass eel recruitment in Atlantic estuaries: a first tidal period of increasing recruitment from 1 November to the neap tide of February (6 February in 2002 and 11 February in 2003), a second tidal period of decreasing recruitment from the neap tide of February to the neap tide of May (6 May in 2002 and 9 May in 2003), and a third tidal period of late recruitment from the neap tide of May onwards (Elie \& Rochard 1994, Beaulaton \& Castelnaud 2005). Hence, the tidal period effect also captured seasonal effects, and was positively correlated with water temperatures. (6) Finally, tides were separated in 2 classes around the
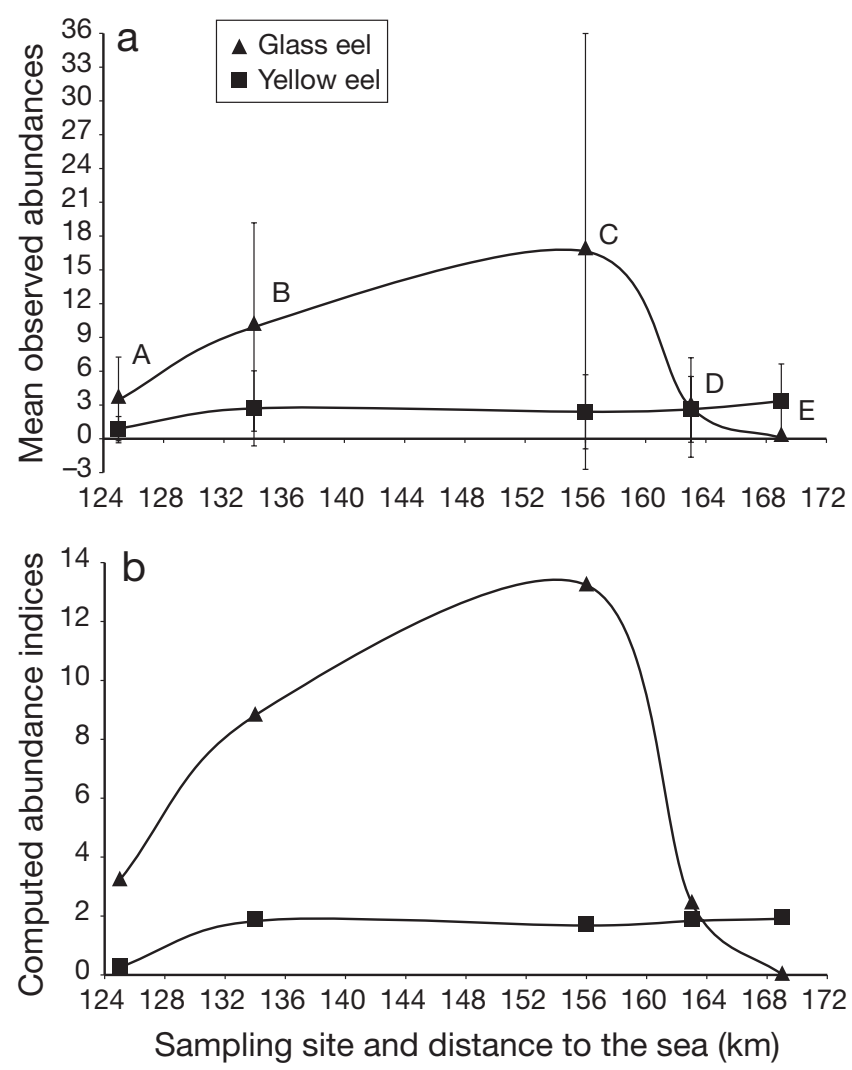

Fig. 1. Anguilla anguilla. (a) Smoothed representation of observed mean abundance $( \pm \mathrm{SD})$ of glass eels and newly transformed yellow eels at 5 sampling sites (A, B, C, D, E) in the tidal area of the Dordogne River (raw data). SD are large because of the high number of 0 catches. (b) Smoothed representation of predicted abundance indices corrected for effects of covariates (as given in Table 2)

French tidal stage 80 (corresponding to strong or weak tidal height).

From the 4 statistical models (Table 2) we obtained estimates for the effects of each sampling site on presence and abundance of fish, correcting for the effects of other covariates. Having obtained these fitted estimates for the probability $p$ of a non-zero abundance and for mean positive abundance $\mu$ for each sampling site, site-specific predicted abundance indices in Fig. 1 were given by $p \mu$ (Stefánsson 1996).

\section{RESULTS}

\section{Spatial distribution of glass eels vs. small yellow eels}

Both presence and abundance of glass eels Anguilla anguilla were significantly affected by the sampling site effect (Table 2); abundance markedly increased with increased distance from the river mouth and peaked at 
Table 2. Details of the different generalised linear models (GLM) used to model abundance of glass eels and newly transformed yellow eels Anguilla anguilla around the tidal limit of the Dordogne River. GLM selection was based on the parsimony principle (lowest Aikaike's information criterion) among a set of statistical models, including an exhaustive combination of candidate effects. Effects were incorporated without interaction in the model's formulation (i.e. strictly additive formulation). Significance of effects is based on a Type III sum of squares. See 'Results' for detailed description of how each covariate affected fish presence and abundance

\begin{tabular}{|c|c|c|c|c|c|c|c|c|}
\hline $\begin{array}{l}\text { GLM } \\
\text { number }\end{array}$ & $\begin{array}{l}\text { Development } \\
\text { stage }\end{array}$ & $\begin{array}{c}\text { Dependent } \\
\text { variable }\end{array}$ & $\begin{array}{c}\text { Link } \\
\text { function }\end{array}$ & $\begin{array}{l}\text { Distribution } \\
\text { function }\end{array}$ & Effects & $\mathrm{df}$ & $\chi^{2}$-value & $\mathrm{p}$ \\
\hline 1 & Glass eel & Presence & Logit & Binomial & $\begin{array}{c}\text { Sampling site } \\
\text { Tidal period } \\
\text { Number of collectors }\end{array}$ & $\begin{array}{l}4 \\
2 \\
1\end{array}$ & $\begin{array}{l}68.80 \\
27.53 \\
12.82\end{array}$ & $\begin{array}{r}<0.0001 \\
<0.0001 \\
0.0003\end{array}$ \\
\hline 2 & Glass eel & $\begin{array}{c}\text { Positive } \\
\text { abundance }\end{array}$ & Logarithm & Poisson & $\begin{array}{c}\text { Sampling site } \\
\text { Tidal period } \\
\text { Sampling year } \\
\text { River discharge } \\
\text { Tides } \\
\text { Number of collectors }\end{array}$ & $\begin{array}{l}4 \\
2 \\
1 \\
3 \\
1 \\
1\end{array}$ & $\begin{array}{r}377.87 \\
136.65 \\
137.44 \\
59.87 \\
84.77 \\
11.35\end{array}$ & $\begin{aligned}<0.0001 \\
<0.0001 \\
<0.0001 \\
<0.0001 \\
<0.0001 \\
\quad 0.0008\end{aligned}$ \\
\hline 3 & Yellow eel & Presence & Logit & Binomial & $\begin{array}{c}\text { Sampling year } \\
\text { Sampling site } \\
\text { Number of collectors } \\
\text { Tides }\end{array}$ & $\begin{array}{l}1 \\
4 \\
1 \\
1\end{array}$ & $\begin{array}{r}23.34 \\
20.72 \\
8.21 \\
4.08\end{array}$ & $\begin{array}{r}<0.0001 \\
0.0004 \\
0.0042 \\
0.0435\end{array}$ \\
\hline 4 & Yellow eel & Positive & Logarithm & Poisson & $\begin{array}{c}\text { Number of collectors } \\
\text { River discharge } \\
\text { Sampling site } \\
\text { Tidal period } \\
\text { Sampling year } \\
\text { Tides }\end{array}$ & $\begin{array}{l}1 \\
3 \\
4 \\
2 \\
1 \\
1\end{array}$ & $\begin{array}{r}16.18 \\
16.49 \\
15.34 \\
8.35 \\
4.95 \\
4.32\end{array}$ & $\begin{array}{r}<0.0001 \\
0.0009 \\
0.0040 \\
0.0154 \\
0.0260 \\
0.0377\end{array}$ \\
\hline
\end{tabular}

the break point of tidal streams (Site C), indicating accumulation at this point of the watershed (Fig. 1). Then, abundance decreased sharply at Site D, reaching $18 \%$ of the abundance encountered at Site C. At Site E, abundance of glass eels was almost zero (Fig. 1). Both presence and abundance of newly transformed yellow eels were also significantly affected by the sampling site effect (Table 2). However, their distribution pattern was markedly different from that of glass eels, since abundance increased upstream of Site A and then remained nearly constant through Site E (Fig. 1).

\section{Hydrodynamic forcing and temporal trends in abundance}

Abundance of glass eels (but not presence) decreased with an increase of both tides and river discharge. In contrast, abundance of small yellow eels increased with river discharge, while both presence and abundance also decreased with increasing tides (Table 2). Abundance of glass eels and both presence and abundance of newly transformed yellow eels decreased during the second sampling year (Table 2). The highest abundance of glass eels were found during the second tidal period, while the highest abundance of newly transformed yellow eels were found during the third tidal period ( 1 tidal period, i.e. $\sim 3 \mathrm{mo}$, after peaking glass eel abundance).

\section{DISCUSSION}

In numerous marine organisms, the end of larval metamorphosis triggers a behavioural switch from migration to settlement. Our study suggests a similar ontogenetic pattern in the European eel Anguilla anguilla. Glass eels arriving from the sea and migrating up-estuary accumulated at the break point of tidal streams. This accumulation may be compared to a traffic jam due to a narrowing road. Here, the traffic jam is due to the loss of tidal advection available for STST. Upstream of the break point of tidal streams, only counter-current swimming glass eels were still able to continue river colonisation. Our data suggest that only $18 \%$ was able to switch to counter-current migration, and that these individuals transformed into yellow eels before reaching Site E. Switch to counter-current swimming by glass eels is associated with high thyroid hormone levels $\left(\mathrm{TH}\right.$, the thyroxine $\mathrm{T}_{4}$ and triiodothyronine $\mathrm{T}_{3}$ ), which stimulate locomotor activity (Edeline et al. 2004, 2005a). It is likely that not all individuals have a thyroid gland activity high enough to switch from STST to active counter-current river colonisation. High thyroid status in counter-current swimmers may also explain their rapid transformation into yellow eels, because THs regulate the suite of morphological and physiological transformations associated with metamorphosis (reviewed by Edeline et al. 2005a). 
The distribution pattern of newly transformed yellow eels was quite different from that of glass eels, suggesting a pronounced ontogenetic change in dispersal behaviour. Maintenance of upstream migratory movements by newly transformed yellow eels would have induced increased abundance upstream of the site of accumulation (Site $\mathrm{C}$ ). Instead, abundance remained almost constant upstream of Site A, suggesting loss of upstream migratory behaviour (i.e. settlement) at the onset of the growth phase. Accordingly, transformation into a yellow eel is related to a decrease in thyroid gland activity (Callamand \& Fontaine 1942, Jegstrup \& Rosenkilde 2003), an endocrine change that could induce settlement. Homogenous distribution of newly transformed yellow eels around the point where they initially accumulated as glass eels further suggests density-dependent dispersal. Accordingly, several recent studies suggest that yellow eel movements in rivers mainly result from (random) dispersal (Smogor et al. 1995, Feunteun et al. 2003, Ibboston et al. 2003). In newly transformed yellow eels, density-dependent dispersal may be related to the acquisition of fully developed feeding capacities that trigger competition for food and space and allow cannibalism. Yellow eels severely compete for food intake, and are strongly cannibalistic (Tesch 1977, Knights 1987).

Ultimately, growing fast is crucial for eels. Increased size brings higher social rank; protects from cannibals and predators; reduces the duration of the continental growth phase, because maturation is size dependent (Vøllestad 1992); and enhances fecundity and swimming capacity. Migration to the continental feeding grounds probably evolved because freshwater habitats are more productive than marine habitats at the tropical latitudes where the genus Anguilla appeared (Gross et al. 1988, Aoyama et al. 2001). At temperate latitudes, marine and estuarine habitats are more productive than freshwaters (Gross et al. 1988), and thus seem more favourable for growth maximisation. In addition, migration results in a trade-off with growth (Edeline 2007), as confirmed by experiments showing that glass eel migratory propensity is negatively correlated to subsequent juvenile growth performance over a period of 2 mo (Edeline et al. 2005b). Hence, settlement at the onset of the juvenile phase, rapidly stopping migration and promoting the colonisation of productive marine or estuarine habitats, may be seen as a growth-maximising developmental tactic. Subsequently, post-settlement, density-dependent dispersal allows optimal habitat utilisation. Settlement is a complex trait involving profound morphological, physiological and behavioural changes. Hence, it is likely that, like any other complex trait (Futuyma 1997), the timing of settlement is influenced by significant additive genetic variance, allowing the evolution of disper- sal ontogeny (Edeline 2007). Such genetic variability could explain the existence of alternative dispersal tactics of minority individuals settling at the glass eel stage or maintaining density-independent, upstream migration at the yellow stage.

Acknowledgements. We thank Pr. L. A. Vøllestad (University of Oslo) and Dr. S. Dufour (MNHN Paris) for comments on the manuscript. C. Briand (IAV, La Roche Bernard) provided eel collectors and a critical reading of an early version of the manuscript. We are indebted to Claude Durand, professional fisherman on the Dordogne River, for sharing with us his experience of the river and providing a permanent boat anchorage. We are grateful to M. Vignaud and all the Gironde team of the French Conseil Supérieur de la Pêche (CSP) for their invaluable support throughout this study. We also thank all personnel of the Cemagref who participated in sampling: A. Guibert, C. Roqueplo, F. Bouin, M. Lepage, G. Castelnaud, L. Brosse, A. Lochet and C. Gazeau. Dr. F.-A. Weltzien (University of Oslo) kindly edited the English. This work was partly supported by research grants from the Région Aquitaine and from the French Ministère de l'Ecologie.

\section{LITERATURE CITED}

Aoyama J, Nishida M, Tsukamoto K (2001) Molecular phylogeny and evolution of the freshwater eel, genus Anguilla. Mol Phylogenet Evol 20:459-459

Beaulaton L, Castelnaud G (2005) The efficiency of selective tidal stream transport in glass eel entering the Gironde (France). Bull Fr Pêche Piscic 378/79:5-21

Callamand O, Fontaine M (1942) L'activité thyroïdienne de l'anguille au cours de son développement. Arch Zool Exp Gen 82:129-136

Edeline E (2007) Adaptive phenotypic plasticity of eel diadromy. Mar Ecol Prog Ser 341:229-232

Edeline E, Dufour S, Briand C, Fatin D, Elie P (2004) Thyroid status is related to migratory behavior in Anguilla anguilla glass eels. Mar Ecol Prog Ser 282:261-270

Edeline E, Bardonnet A, Bolliet V, Dufour S, Elie P (2005a) Endocrine control of Anguilla anguilla glass eel dispersal: effect of thyroid hormones on locomotor activity and rheotactic behavior. Horm Behav 48:53-63

Edeline E, Dufour S, Elie P (2005b) Role of glass eel salinity preference in the control of habitat selection and growth plasticity in Anguilla anguilla. Mar Ecol Prog Ser 304: 191-199

Elie P (1979) Contribution à l'étude des montées de civelles d'Anguilla anguilla Linné (Poisson, Téléostéen, Anguilliforme), dans l'estuaire de la Loire: pêche, écologie, écophysiologie et élevage. Thèse de doctorat, Université de Rennes I

Elie P, Rochard E (1994) Migration des civelles d'anguille dans les estuaires, modalités du phénomène et caractéristiques des individus. Bull Fr Pêche Piscic 335:81-98

Elie P, Lecomte-Finiger R, Cantrelle I, Charlon N (1982) Définition des limites des différents stades pigmentaires durant la phase civelle d'Anguilla anguilla L. (poisson téléostéen anguilliforme). Vie Milieu 32:149-157

Feunteun E, Laffaille P, Robinet T, Briand C, Baisez A, Olivier JM, Acou A (2003) A review of upstream migration and movements in inland waters by anguillid eels. Towards a general theory. In: Aida K, Tsukamoto K, Yamauchi K (eds) Eel biology. Springer, Tokyo, p 191-213 
Futuyma DJ (1997) Evolutionary biology. Sinauer, Sunderland Gross MR, Coleman RM, McDowall RM (1988) Aquatic productivity and the evolution of diadromous fish migration. Science 139:1291-1293

Ibboston A, Smith J, Scarlett P, Aprahamian MW (2003) Colonisation of freshwater habitats by the European eel Anguilla anguilla. Freshw Biol 47:1696-1706

Jegstrup IM, Rosenkilde P (2003) Regulation of post-larval development in the European eel: thyroid hormone level, progress of pigmentation and changes in behaviour. J Fish Biol 63:168-175

Knights B (1987) Agonistic behaviour and growth in the European eel, Anguilla anguilla L., in relation to warm-water aquaculture. J Fish Biol 31:265-276

McCleave JD, Wippelhauser GS (1987) Behavioural aspects of selective tidal stream transport in juvenile American eels. Am Fish Soc Symp 1:138-150

Moran NA (1994) Adaptation and constraint in the complex life-cycles of animals. Annu Rev Ecol Syst 25:573-600

Silberschneider V, Pease BC, Booth DJ (2001) A novel artificial habitat collection device for studying resettlement patterns in anguillid glass eels. J Fish Biol 58:1369-1370

Editorial responsibility: Howard Browman (Associate Editorin-Chief), Storebø, Norway
Smogor RA, Angermeier PL, Gaylord CK (1995) Distribution and abundance of American eels in Virginia streams: test of null models across spatial scales. Trans Am Fish Soc 124: 789-803

Sottolicchio A (1999) Modélisation de la dynamique des structures turbides (bouchon vaseux et crême de vase) dans l'estuaire de la Gironde. Thèse de doctorat, Université de Bordeaux I

Stefánsson G (1996) Analysis of groundfish survey abundance data: combining the GLM and delta approaches. ICES J Mar Sci 53:577-588

Tabeta O, Mochioka N (2003) The glass eel. In: Aida K, Tsukamoto K, Yamauchi K (eds) Eel biology. Springer, Tokyo, p $75-87$

Tesch FW (1977) The eel. Chapman \& Hall, London

Vilter V (1945) Développement du tractus gastro-intestinal au cours de la métamorphose de larves d'anguille (civelles). CR Seances Soc Biol Paris 139:223-224

Vøllestad LA (1992) Geographic variation in age and length at metamorphosis of maturing European eel: environmental effects and phenotypic plasticity. J Anim Ecol 61:41-48

Submitted: December 4, 2004; Accepted: March 18, 2007 Proofs received from author(s): August 1, 2007 